\title{
METODE ANUITAS DAN PROPORSIONAL MURABAHAH SEBAGAI BENTUK TRANSPARANSI DAN PUBLIKASI LAPORAN BANK*
}

\author{
Faisal $^{* *}$ \\ Bagian Hukum Perdata, Fakultas Hukum Universitas Malikussaleh, Lhokseumawe \\ Kampus Bukit Indah, Jalan Jawa, Kecamatan Muara Satu, Lhokseumawe, Aceh 24352
}

\begin{abstract}
Proportional and annuity methods are based on PBI 14/14/PBI/2012 on Transparency and Publication Reports of Islamic Banking and SEBI No. 15/26/DPbs/2013 on Implementation of Accounting Guidelines of Islamic Banking in Indonesia. These methods are forms of commitment to bring transparency in the Islamic banks and recognition on financial statement of profit on murabaha. The Annuity method is referred to PSAK 50, PSAK 55 and PSAK 60 because the substance is classified as a form of financing. Proportional method is referred to PSAK 102 because the substance is classified as trading activities.
\end{abstract}

Keywords: annuities, proportional, murabaha, Islamic banks.

\section{Intisari}

Metode anuitas dan proporsional didasarkan pada PBI No. 14/14/PBI/2012 tentang Transparansi dan Publikasi Laporan Bank Syariah dan SEBI No. 15/26/DPbs/2013 tentang Pelaksanaan Pedoman Akuntansi Perbankan Syariah Indonesia. Metode tersebut merupakan bentuk komitmen bank syariah dalam mewujudkan transparansi dan laporan keuangan pada pengakuan keuntungan murabahah. Metode anuitas mengacu pada PSAK 50, PSAK 55, dan PSAK 60 karena secara substansi dikategorikan sebagai bentuk pembiayaan. Metode proporsional mengacu pada PSAK 102 karena secara substansi dikategorikan sebagai bentuk kegiatan jual beli.

Kata Kunci: anuitas, proporsional, murabahah, bank syariah.

\section{Pokok Muatan}

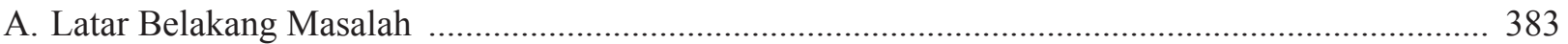

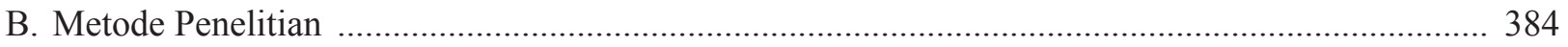

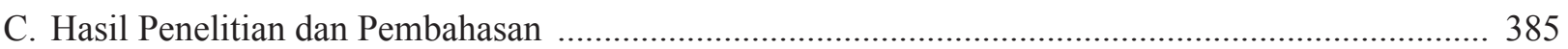

1. Pengaturan Metode Anuitas dan Proporsional dalam Pengakuan Keuntungan Murabahah ....... 385

2. Metode Anuitas dan Proporsional Murabahah sebagai Bentuk Transparansi dan Publikasi

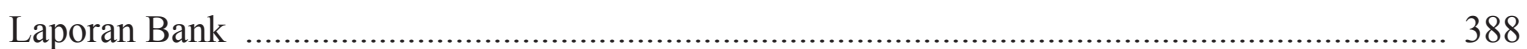

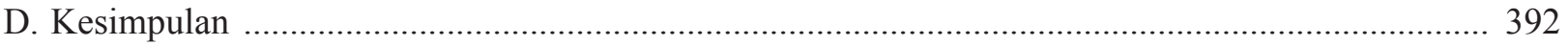

* Penelitian didanai oleh PNBP Fakultas Hukum Universitas Malikussaleh.

** Alamat korespondensi: faichal_fh@yahoo.co.id 


\section{A. Latar Belakang Masalah}

Perkembangan perekonomian di bidang industri perbankan semakin mengalami kemajuan dan persaingan ketat. Perkembangan tersebut tidak hanya secara nasional tetapi juga secara internasional. Hal ini membawa pengaruh bagi industri perbankan di Indonesia. Pengaruh tersebut antara lain adalah penyesuaian dan penggunaan pelbagai aturan ataupun standar di industri perbankan dunia sehingga akan melahirkan sistem perbankan yang kokok, daya saing, dan sesuai standar internasional.

Munculnya pelbagai standar internasional seperti Basel Core Principles atau Core Principles for Effective Banking Supervision yang mengatur tentang prinsip-prinsip dasar sistem pengawasan perbankan. Prinsip-prinsip tersebut diterbitkan oleh the Basel Committee on Banking Supervision bersama dengan beberapa institusi pengawasan perbankan lainnya. Prinsip tersebut diimplementasikan dalam pelbagai macam prosedur dan mekanisme yang diatur melalui Arsitektur Perbankan Indonesia (API). API merupakan suatu kerangka dasar sistem perbankan Indonesia yang bersifat menyeluruh dan memberikan arah, bentuk, dan tatanan industri perbankan untuk rentang waktu lima sampai sepuluh tahun ke depan. ${ }^{1}$ Hal tersebut sesuai dengan tujuan dibentuknya API, yaitu menciptakan sistem pengaturan dan pengawasan bank yang efektif dan mengacu pada standar internasional. ${ }^{2}$

Adapun organisasi yang secara khusus mengatur tentang perbankan syariah, antara lain adalah The Islamic Financial Service Board (IFSB). The Islamic Financial Services Board
(IFSB) merupakan sebuah organisasi penetapan standar internasional yang mempromosikan dan meningkatkan kesehatan dan stabilitas industri jasa keuangan Islam dengan menerbitkan standar kehati-hatian global dan prinsip pedoman untuk industri. IFSB tersebut secara luas mencakup perbankan, pasar modal, dan asuransi. ${ }^{3}$ Organisasi tersebut diresmikan pada 3 November 2002 dan mulai beroperasi pada 10 Maret 2003. IFSB telah mengeluarkan pelbagai macam standar dan prinsipprinsip melalui proses hukum yang panjang, seperti yang diuraikan dalam Surat Pedoman dan Tata Cara Penyajian Standar.

Selain itu, perbankan syariah melakukan juga penyesuaian diri dengan international best practices yang dirumuskan oleh lembaga-lembaga keuangan syariah internasional lainnya. Lembaga tersebut antara lain, Accounting and Auditing Organisation for Islamic Financial Institutions (AAOIFI). ${ }^{4}$ AAOIFI telah mengembangkan dan mempromosikan standar-standar akuntansi Islam. Pada saat ini AAOIFI telah mengeluarkan delapan belas pernyataan standar akuntansi dan audit keuangan Islam. ${ }^{5}$ Lebih lanjut, AAOIFI mempunyai peran dalam mengumumkan dan menafsirkan standar akuntansi, audit, dan tata kelola yang dibuat oleh The Islamic Financial Institutions (IFIs). ${ }^{6}$ Standar-standar AAOIFI tersebut menjadi "the best practices" sehingga dapat digunakan oleh pelbagai macam organisasi mitranya. ${ }^{?}$

Prinsip-prinsip dan aturan yang dikeluarkan oleh organisasi internasional tersebut dapat menjadi standard atau acuan bagi industri perbankan syariah

Bank Indonesia, "Arsitektur Perbankan Indonesia", http://www.bi.go.id/web/id/Perbankan/Arsitektur+Perbankan+Indonesia/, diakses 29 September 2013

Bank Indonesia, “Arsitektur Perbankan Indonesia: Program Peningkatan Kualitas Pengaturan Perbankan", http://www.bi.go.id/web/id/ Perbankan/Arsitektur+Perbankan+Indonesia/Pengaturan, diakses 29 September 2013.

IFSB, "Defining New Standards in Islamic Finance", http://www.ifsb.org/, diakses 20 September 2013.

Bank Indonesia, "Perbankan Syariah: Sekilas Perbankan Syariah di Indonesia", http://www.bi.go.id/web/id/Perbankan/Perbankan+Syariah/, diakses 29 September 2013.

Rifaat Ahmed Abdel Karim, "Accounting and Auditing Standards for Islamic Financial Istitutions", Makalah, disampaikan dalam the Second Harvard University Forum on Islamic Finance: Islamic Finance into the $21^{\text {st }}$ Century Cambridge, Massachusetts.

Samy Nathan Garas, et al., "Shari'a Supervision of Islamic Financial Institutions”, Journal of Financial Regulation and Compliance, Vol. 18, No. 4, 2010, hlm. 387.

Bill Maurer, "Anthropological and Accounting Knowledge in Islamic Banking and Finance: Rethinking Critical Accounts", The Journal of the Royal Anthropological Institute, Vol. 8, No. 4, Desember 2002, hlm. 650. 
di Indonesia. Prinsip-prinsip tersebut antara lain adalah prinsip yang menuntut industri perbankan untuk melakukan pembukuan (akuntansi) yang akurat dan transparan dalam pelbagai informasi secara komprehensif. Dewan Standar Akuntansi Keuangan (DSAK) dari Ikatan Akuntan Indonesia (IAI), Bank Indonesia, dan lembaga keuangan Islam telah melakukan kerja sama untuk mengeluarkan pelbagai macam Pernyataan Standar Akuntansi Keuangan (PSAK) bagi perbankan syariah. ${ }^{8}$

Transparansi dan publikasi laporan keuangan bank menjadi aturan untuk diterapkan di dalam industri perbankan syariah di Indonesia. Transparansi dan publikasi tersebut berkembang seiring dengan perkembangan laporan keuangan bank. Antara lain, pelaporan keuangan dengan menggunakan metode anuitas dan proporsional dalam pengakuan keuntungan murabahah. Metode anuitas dan proporsional murabahah adalah pengakuan keuntungan murabahah dengan cara penghitungan terhadap harga jual yang terdiri dari angsuran harga pokok/harga beli dengan angsuran margin keuntungan. Berdasarkan pembukuan akuntansi, metode tersebut mempunyai cara penghitungannya masing-masing. Metode proporsional merupakan metode yang sudah lama (biasa) diterapkan di dalam praktik perbankan syariah di dalam melakukan pengakuan keuntungan murabahah. Sedangkan metode anuitas merupakan metode yang baru pada lembaga keuangan syariah di Indonesia. Oleh karena itu, kedua metode tersebut menarik dilakukan kajian lebih lanjut. Berdasarkan latar belakang masalah tersebut, maka dirumuskan permasalahan, yaitu: Pertama, bagaimanakah pengaturan metode anuitas dan proporsional dalam pengakuan keuntungan murabahah pada bank syariah. Kedua, bagaimanakah metode anuitas dan proporsional dalam pengakuan keuntungan murabahah sebagai bentuk transparansi dan publikasi laporan bank syariah.

\section{B. Metode Penelitian}

Kajian ini merupakan kajian hukum normatif yang bersifat deskriptif analitis. Sifat deskriptif analitis dimaksudkan supaya dari hasil kajian ini dapat diperoleh gambaran mengenai kebenaran hukum apa adanya melalui analisis secara mendalam terhadap substansi hukum berkaitan dengan metode anuitas dan proporsional murabahah sebagai bentuk transparansi dan pelaporan bank. Hal ini sesuai dengan maksud dari kajian hukum yaitu mencari kebenaran hukum ${ }^{9}$ yang terdapat dalam hukum positif. Pengumpulan data dilakukan melalui kajian pustaka dengan menggunakan data sekunder. Penelusuran data sekunder dilakukan di perpustakaan dengan tujuan mendapatkan bahan hukum berupa norma atau kaidah yang terdiri atas asas-asas hukum dan nilai-nilai hukum. Data sekunder yang digunakan dalam kajian ini diperoleh dari pelbagai bahan hukum primer dan sekunder. Bahan hukum primer merupakan bahan-bahan hukum yang mengikat, ${ }^{10}$ yang terdiri atas UndangUndang Nomor 21 Tahun 2008 tentang Perbankan Syariah; Peraturan Bank Indonesia Nomor 14/14/ PBI/2012 tentang Transparansi dan Publikasi Laporan Bank; Surat Edaran Bank Indonesia (SEBI) Nomor 15/26/DPbs/2013 tentang Pelaksanaan Pedoman Akuntansi Perbankan Syariah Indonesia (PAPSI); Fatwa Dewan Syariah Nasional Nomor 84/DSN-MUI/XII/2012 tentang Metode Pengakuan Pendapatan Murabahah di Lembaga Keuangan Syariah (LKS); dan Fatwa Dewan Syariah Nasional Nomor 4/DSN-MUI/IX/2000 tentang Murabahah. Selain itu, kajian ini menggunakan bahan hukum sekunder yang merupakan bahan hukum yang memberikan penjelasan bagi bahan hukum primer ${ }^{11}$

\footnotetext{
Tim Lindsey, "Between Piety and Prudence: State Syariah and the Regulation of Islamic Banking in Indonesia", Sydney Law Review, 34 Sydney L. Rev. 107, Maret 2012, hlm. 119.

Menurut sifat kebenaran hukum yang diungkapkan dalam kajian ini termasuk kebenaran hukum kualitatif, karena mengungkapkan kesesuaian suatu ketentuan hukum yang menetapkan prasyarat kualitas tertentu yang harus dipenuhi. Lihat F. Sugeng Istanto, 2007, Penelitian Hukum, Ganda, Yogyakarta, hlm. 47.

10 Soerjono Soekanto, 2007, Pengantar Penelitian Hukum, Universitas Indonesia Press, Jakarta, hlm. 52.
}

11 Ibid. 
yang terdiri atas buku-buku, artikel-artikel jurnal, artikel koran, dan makalah yang mempunyai kaitan dengan permasalahan kajian hukum ini.

Sebelum data dianalisis terlebih dahulu dilakukan pengorganisasian data terhadap data sekunder yang telah dikumpulkan melalui studi dokumen. Selanjutnya data tersebut dikumpulkan dan dikelompokkan ke dalam klasifikasi tertentu terkait rumusan masalah, serta dicatat secara sistematis untuk memudahkan dalam proses analisis. Analisis yang dipergunakan dalam penelitian ini adalah analisis kualitatif secara yuridis normatif berdasarkan konsep-konsep yang diperoleh melalui studi dokumen. Berdasarkan analisis tersebut diharapkan dapat memperoleh gambaran yang menyeluruh mengenai kaidah-kaidah hukum yang berkaitan dengan permasalahan.

\section{Hasil Penelitian dan Pembahasan}

1. Pengaturan Metode Anuitas dan Proporsional dalam Pengakuan Keuntungan Murabahah

Bank Indonesia mempunyai peran di dalam mendorong perbankan syariah di Indonesia ke arah perkembangan perbankan yang sehat, kuat, dan daya saing tinggi sesuai dengan perkembangan standar internasional. Perkembangan standar internasional antara lain ialah mempunyai akuntansi dan pelaporan bank yang baik dan profesional. Oleh karena itu, diperlukan peningkatan transparansi kondisi keuangan dan kinerja bank melalui publikasi pelaporan bank sehingga memudahkan penilaian bagi publik dan pelaku pasar.

Peningkatan transparansi kondisi keuangan dan publikasi pelaporan bank mengikuti perkembangan kemajuan akuntansi terkini. Salah satu bentuk akuntansi tersebut adalah menggunakan metode anuitas dan proporsional dalam pengakuan keuntungan murabahah. Hal tersebut disebabkan murabahah merupakan salah satu bentuk pembiayaan berdasarkan transaksi jual beli barang yang paling populer dengan bentuk yang sederhana ${ }^{12}$ sehingga banyak digunakan di dalam perbankan syariah di Indonesia dan bahkan di dunia internasional.

Berdasarkan data yang dirilis oleh Bank Indonesia, pada tahun 2011 market share perbankan syariah terhadap perbankan nasional telah mencapai sekitar 3,8\%. Masih dalam publikasi yang sama, disebutkan bahwa pertumbuhan perbankan syariah ini diantaranya didukung dengan peningkatan penyaluran dana masyarakat yang cukup tinggi (meningkat sebesar 46,43\% dari Oktober 2010 ke Oktober 2011). Salah satu skema pembiayaan yang mendominasi dalam penyaluran dana masyarakat adalah melalui akad murabahah (berjumlah sekitar $42,42 \%$ dari total penyaluran dana pada periode 2010 sampai Oktober 2011). ${ }^{13}$

Pembiayaan murabahah telah mendominasi penyaluran dana kepada masyarakat melebihi $80 \%$ dibandingkan dengan pembiayaan lainnya. Rodney Wilson menyatakan, "Murabaha has become by far the most widely used Islamic financing instrument, accounting for over 80 per cent of Islamic financing". ${ }^{14}$ Begitu juga, komposisi pembiayaan yang diberikan Bank Umum Syariah dan Unit Usaha Syariah (Financing Composition of Islamic Commercial Bank and Islamic Business Unit) pada Data Statistik Perbankan Syariah (Islamic Banking Statistics), menunjukkan bahwa total komposisi pembiayaan perbankan syariah adalah 174.486 , yang terdiri dari pembiayaan berdasarkan murabahah tercatat 104.718, mudharabah tercatat 13.281, musyarakah tercatat 35.997 , istishna' tercatat 508, dan selebihnya merupakan pembiayaan lainnya. ${ }^{15}$

Dominasi pembiayaan murabahah dapat dilihat juga pada beberapa bank syariah, misalnya pembiayaan yang dilakukan oleh Bank Mega

\footnotetext{
Atif Hanif, "Islamic Finance: an Overview", International Energy and Taxation Law Review, Vol. 9, No. 15, Januari 2008, hlm. 11. Deloitte, "Murabahah Anuitas Perspektif Baru Lembaga Keuangan Syariah", http://www.deloitte.com/id, diakses 20 September 2013.

Rodney Wilson, "The Issue of Interest and the Islamic Financing Alternatives", Journal of International Banking Law, Vol. 13, No. 1, 1997, hlm. 28 .

15 Bank Indonesia, "Statistik Perbankan Syariah (Islamic Banking Statistics) Juli 2013”, http://www.bi.go.id/web/id/Statistik/Statistik+Perbankan/ Statistik+Perbankan+Syariah/sps_0713.htm, diakses 4 Oktober 2013.
} 
Syariah $(\mathrm{BSM})^{16}$ dan Unit Usaha Syariah (UUS) pada Bank Nasional Indonesia (BNI). ${ }^{17}$ Kedua bank syariah tersebut, penyaluran dana dalam bentuk pembiayaan murabahah lebih dominan dibandingkan dengan pembiayaan lainnya. Dominasi pembiayaan murabahah karena memiliki banyak kesamaan dengan pola pembiayaan kredit sehingga lebih mudah diterima masyarakat. ${ }^{18}$ Pembiayaan tersebut pada dasarnya merupakan transaksi jual beli yang kemudian menjadi transaksi pembiayaan yang diterapkan pada perbankan syariah. Maulana Taqi Usmani menyatakan, "Originally, murabahah is a particular type of sale and not a mode of financing". 19

Murabahah adalah perjanjian jual-beli barang pada harga asal dengan tambahan keuntungan/ margin yang disepakati. ${ }^{20}$ Dengan kata lain, nasabah dapat membeli produk yang dibutuhkannya tetapi tidak mampu membayar secara sekaligus sehingga dilakukan penangguhan pembayaran. Meskipun, nasabah harus membayar lebih tinggi dari harga pembelian asli. ${ }^{21}$ Ciri khas murabahah adalah penjual mengungkapkan biaya yang sebenarnya dan meminta keuntungan dalam bentuk persentase dari biaya yang dikeluarkan. ${ }^{22}$

Di dalam Islam, murabahah merupakan salah satu bentuk jual beli yang bersifat amanah. Jual beli bersifat amanah dapat diartikan sebagai jual beli transparan, yaitu penjual mempunyai keharusan untuk memberitahukan harga pokok dan keuntungan yang diambil dari barang yang dijual tersebut kepada pembeli secara jujur. Ketidakjujuran dalam melakukan transaksi jual beli yang bersifat amanah termasuk di dalamnya melakukan tindakan berupa diam semata maka dapat diartikan sebagai salah satu bentuk penipuan. ${ }^{23}$ Di dalam sistem hukum di AS, perbuatan berupa tidak memberitahukan atau merahasiakan informasi sehubungan dengan pembelian atau penjualan barang dianggap sebagai bentuk penipuan. Demikian juga, di Inggris, tidak memberitahukan informasi tersebut dianggap sama saja telah melakukan tindak pidana penipuan. Di Afrika Selatan, merahasiakan informasi di bidang transaksi efek dianggap mirip dengan melindungi kecacatan tersembunyi di dalam melakukan penjualan barang. Hal tersebut merupakan melakukan perbuatan transaksi yang dilarang. ${ }^{24}$ Oleh karena itu, di dalam transaksi jual beli harus dilakukan secara amanah.

Di dalam praktik bank syariah, pemberian pembiayaan murabahah dijadikan sebagai ukuran dalam menilai karakter nasabah. Hal tersebut karena di dalamnya mengandung janji ( $w a{ }^{\prime} a d$ ) yang harus ditepati oleh nasabah dan janji tersebut secara hukum harus dipatuhi sebagai pengecualian dari aturan umum. ${ }^{25}$ Nasabah melakukan pemesanan barang dan berjanji untuk membeli pesanan tersebut secara murabahah. Janji yang dilakukan nasabah untuk membeli barang pesanan bersifat mengikat nasabah tersebut. $^{26}$ Al-Qaradhawi berpendapat bahwa

16 Total pembiayaan yang disalurkan oleh Bank Mega Syariah sebesar $80 \%$ didominasi oleh prinsip murabahah, sisanya prinsip mudharabah dan musyarakah. Lihat Ani Murdiati, "Ekonomi \& Bisnis Syariah: Pembiayaan BMS Dominan Murabahah", Harian Republika, 1 April 2009, hlm. 20.

17 Begitu juga pembiayaan Wirausaha dan Tunas Usaha pada Unit Usaha Syariah (UUS) BNI didominasi oleh prinsip murabahah dengan komposisi melebihi 50 persen, sedangkan sisanya berdasarkan prinsip musyarakah. Lihat Ismi Kushartanto, "Ekonomi \& Bisnis: Pembiayaan UMKN BNI Syariah Capai Rp195 Miliar”, Harian Republika, 22 April 2009, hlm. 20.

18 Nur Sanita Nasution, "Pajak Berganda Menghambat Perbankan Syariah", Jurnal Ekonomi Syariah Muamalah, Vol. 6, Mei 2009, hlm. 56.

9 Maulana Taqi Usmani, "Murabahah", http://www.accountancy.com.pk/docs /islam_murabahah. Pdf, diakses 4 Oktober 2013.

Pengertian pada Penjelasan Fatwa No. 04/DSN-MUI/IV/2000 tentang Murabahah.

21 Salma Taman, "The Concept of Corporate Social Responsibility in Islamic Law", Indiana International \& Comparative Law Review, 21 Ind. Int'l \& Comp. L. Rev. 481, 2011, hlm. 501.

22 Nima Mersadi Tabari, "Islamic Finance and the Modern World: the Legal Principles Governing Islamic Finance in International Trade", Company Lawyer, Vol. 31, No. 8, Januari 2010, hlm. 252.

23 Syamsul Anwar, 2007, Studi Hukum Islam Kontemporer, RM Books, Jakarta, hlm. 168. Lebih lanjut, ia menyatakan bahwa yang dimaksud dengan diam semata, adalah penjual tidak memberikan informasi kepada pembeli tentang sesuatu yang perlu diketahui, misalnya barang yang dijual tersebut diperoleh secara hutang atau cicilan.

Siti Faridah Abdul Jabbar, "Insider Dealing: Fraud in Islam?”, Journal of Financial Crime, Vol. 19, No. 2, 2012, hlm. 145.

Nima Mersadi Tabari, Loc.cit.

Ismail Wisham, et al., "Special Legal Features of the Islamic Wa'd or Pledge: Comparison with the Conventional Law on Promise Within the Sphere of Islamic Finance", International Journal of Law and Management, Vol. 53, No. 3, 2011, hlm. 227. 
apapun yang mengikat secara agama mengikat pula secara hukum. ${ }^{27}$ Oleh karena itu, Grameen Bank menggunakan pembiayaan murabahah untuk mengukur karakter dan kesanggupan nasabah. Nasabah kemudian diberi pilihan untuk meneruskan pembiayaan murabahah atau menggantikannya dengan pembiayaan musyarakah. Pemberian pilihan tersebut apabila nasabah dinilai telah berhasil dengan penerapan pembiayaan murabahah. Hal ini dinyatakan oleh Ehsan Habib Feroz dan Blake Goud sebagai berikut:

Our model begins with providing carefully self-selected client groups with murabaha contracts beforeprovidingmusharakafinance. The murabaha financing agreement includes fixed payments each period of repayment and therefore is easier to administer and can be used to screen out potentially problematic clients who are most likely to default. Those clients who are in groups with successful repayment of the murabaha finance will have a choice between murabaha and musharaka financing in the future. ${ }^{28}$

Dominasi pembiayaan murabahah dalam perbankan syariah disikapi dengan dikeluarkannya pelbagai macam aturan sehingga murabahah yang dilakukan oleh bank syariah sesuai dengan prinsip syariah dan pelaporan akuntansi syariah. Metode anuitas merupakan langkah yang digunakan untuk melakukan pelaporan keuangan melalui akuntansi syariah selama ini, bahkan metode anuitas dalam pengakuan keuntungan murabahah dianggap sebagai perspektif baru dalam lembaga keuangan syariah. ${ }^{29}$

Pengaturan penggunaan metode anuitas dan proporsional dalam pengakuan keuntungan murabahah dapat ditelusuri melalui diperlukannya kegiatan bank syariah melakukan pelaporan keuangan secara transparan dan terpublikasi. Hal tersebut selaras dengan Peraturan Bank Indonesia (PBI) No. 14/14/PBI/2012 tentang Transparansi dan Publikasi Laporan Bank. Peraturan tersebut menghendaki bank syariah dapat melakukan transparansi dan laporan keuangan bank. Perwujudan transparansi dan laporan keuangan bank tersebut dilakukan dengan pelaporan akuntansi secara baik melalui metode anuitas dan proporsional.

Di dalam praktik perbankan syariah, metode akuntansi yang biasa digunakan dalam pengakuan keuntungan murabahah adalah metode proporsional. Sedangkan metode anuitas masih dianggap sebagai metode baru, sehingga diperlukan penguatan dari sudut syar'inya (hukum Islam). Berhubungan dengan hal tersebut, Dewan Syariah Nasional telah mengeluarkan Fatwa Nomor 84/DSN-MUI/XI/2012 tentang Metode Pengakuan Keuntungan Pembiayaan Murabahah di Lembaga Keuangan Syariah (LKS). Fatwa tersebut menyatakan bahwa pengakuan keuntungan murabahah secara proporsional boleh dilakukan selama masih sesuai dengan kebiasaan yang berlaku di kalangan Lembaga Keuangan Syariah. Fatwa tersebut juga menyatakan bahwa pengakuan keuntungan pembiayaan murabahah dalam bisnis yang dilakukan oleh Lembaga Keuangan Syariah boleh dilakukan secara proporsional dan secara anuitas selama sesuai dengan kebiasaan yang berlaku di kalangan Lembaga Keuangan Syariah.

Fatwa Nomor 84/DSN-MUI/XI/2012 telah menunjukkan eksistensi kedua metode tersebut dapat dibenarkan secara syar'i. Bagi praktisi bank syariah, metode proporsional dapat langsung diterapkan dengan menggunakan Pernyataan Standar Akuntansi Keuangan (PSAK Nomor 102) tentang Murabahah. Namun, penggunaan metode anuitas dalam pengakuan keuntungan murabahah tidak diatur dalam PSAK 102 tersebut, sehingga Ikatan Akuntansi Islam (IAI) mengeluarkan Bulletin Teknis (Bultek) 9. Bultek 9 tersebut bertujuan untuk penyeragaman perlakuan akuntansi

\footnotetext{
Ali Abdulrahim Ali, "The Role of Islamic Jurisprudence in Finance and Development in the Muslim World”, Company Lawyer, Vol. 31, No. 4, Maret 2010, hlm. 124.

28 Ehsan Habib Feroz, et al., "Grameen La Riba Model: A Strategy for Global Poverty Alleviation", http://ssrn.com/abstract=1257859, diakses 4 Oktober 2013.

29 Deloitte, Loc.cit.
} 
atas pembiayaan murabahah yang keuntungannya diakui dengan menggunaan metode anuitas.

Metode anuitas dalam pengakuan keuntungan pembiayaan murabahah secara substansi dikategorikan sebagai kegiatan pembiayaan (financing). Akuntansi untuk pembiayaan murabahah yang substansinya dikategorikan sebagai kegiatan usaha pembiayaan mengacu pada PSAK Nomor 50 (Revisi 2010) tentang Instrumen Keuangan: Penyajian, PSAK Nomor 55 (Revisi 2005) Instrumen Keuangan: Pengakuan dan Pengukuran, dan PSAK Nomor 60 tentang Instrumen Keuangan: Pengungkapan. Termasuk di dalamnya adalah PSAK Nomor 48 (Revisi 2009) tentang Penurunan Nilai Aset.

Sehubungan dengan diterbitkannya Peraturan Bank Indonesia Nomor 14/14/PBI/2012 tentang Transparansi dan Publikasi Laporan Bank dan penyeragaman pengaturan PSAK tersebut maka diperlukan ketentuan mengenai pelaksanaan pedoman akuntansi perbankan syariah di Indonesia. Pada tanggal 10 Juli 2013 diterbitkan Surat Edaran Bank Indonesia Nomor 15/26/DPbs/2013 tentang Pelaksanaan Pedoman Akuntansi Perbankan Syariah Indonesia (PAPSI). Dengan diterbitkan SEBI tersebut telah dilakukan penyesuaian atas PAPSI 2003 menjadi PAPSI 2013.

PAPSI 2013 merupakan pedoman dalam penyusunan dan penyajian laporan keuangan Bank Syariah. Termasuk di dalamnya pengakuan terhadap metode anuitas dan proporsional yang tercantum di dalam Fatwa Dewan Syariah Nasional Nomor 84/ DSN-MUI/XII/2012 tanggal 21 Desember 2012 tentang Metode Pengakuan Pendapatan Murabahah di Lembaga Keuangan Syariah. Dengan demikian, pengakuan pendapatan murabahah pada Bank Syariah dapat dilakukan dengan menggunakan metode anuitas dan metode proporsional. Selain itu, pengakuan pendapatan tersebut hanya dapat digunakan untuk pengakuan pendapatan pembiayaan atas dasar transaksi jual beli dan tidak bertentangan dengan prinsip syariah.

\section{Metode Anuitas dan Proporsional Murabahah sebagai Bentuk Transparansi dan Publikasi Laporan Bank}

Sistem keuangan Islam yang berlandaskan pada nilai-nilai Al-qur'an mempunyai keunggulan dalam penerapannya di era kompleksitas dan kapitalisme. Beberapa keunggulan sistem tersebut, antara lain: Pertama, prinsip dan larangan dalam sistem keuangan Islam bersifat universal, fleksibel, dan dapat disesuaikan dengan kebutuhan masyarakat. Kedua, literatur tentang keuangan Islam cukup banyak tersedia; dan Ketiga, dukungan yang kuat dan koordinasi antara negara-negara dan kelembagaan yang memungkinkan sistem keuangan Islam muncul secara sistematis dan kompetitif. Proses tersebut melahirkan pelbagai macam standarisasi untuk membangkitkan kepercayaan investor. Keempat, keuangan Islam memberikan nilai-nilai etis dan keadilan. ${ }^{30}$

Keunggulan sistem keuangan Islam secara perlahan-lahan mulai diterapkan dalam lembaga keuangan syariah. Antara lain adalah penerapan akuntansi yang berbasis syariah. Hal tersebut ditunjukkan dengan keluarnya Fatwa Dewan Syariah Nasional Nomor 84/DSN-MUI/XII/2012 tanggal 21 Desember 2012 tentang Metode Pengakuan Pendapatan Murabahah di Lembaga Keuangan Syariah. Di dalam fatwa tersebut dinyatakan bahwa pengakuan pendapatan murabahah untuk bank syariah dapat dilakukan dengan menggunakan metode anuitas dan proporsional.

Berdasarkan fatwa tersebut, yang dimaksud metode anuitas (thariqah al-hisab al-tanazuliyyah/ thariqah al-tanaqushiyyah) adalah pengakuan keuntungan yang dilakukan secara proporsional atas jumlah sisa harga pokok yang belum ditagih dengan mengalikan persentase keuntungan terhadap jumlah sisa harga pokok yang belum ditagih (al-atsman al-mutabaqqiyah). ${ }^{31}$ Lebih lanjut, metode anuitas adalah keuntungan yang diperoleh dari perhitungan secara anuitas. Perhitungan anuitas adalah suatu

\footnotetext{
Mohd Yazid Bin Zul Kepli, "Islamic Finance in Hong Kong”, Hong Kong Law Journal, Vol. 42, No. 3, 2012, hlm. 2.

Ketentuan Umum angka (1) Fatwa Dewan Syariah Nasional Nomor 84/DSN-MUI/XII/2012 tentang Metode Pengakuan Pendapatan Murabahah di Lembaga Keuangan Syariah (LKS).
} 
cara pengembalian pembiayaan dengan pembayaran angsuran harga pokok dan margin keuntungan secara tetap. Perhitungan ini akan menghasilkan pola angsuran yang semakin membesar dan margin keuntungan yang semakin menurun. ${ }^{32}$

Adapun metode proporsional (thariqah mubasyirah) adalah pengakuan keuntungan yang dilakukan secara proporsional atas jumlah piutang (harga jual, tsaman) yang berhasil ditagih dengan mengalikan persentase keuntungan terhadap jumlah piutang yang berhasil ditagih (al-atsman al-muhashshalah). ${ }^{33}$ Dengan kata lain, metode proporsional (flat) adalah perhitungan keuntungan terhadap nilai harga pokok pembiayaan secara tetap dari satu periode ke periode lainnya, walaupun debetnya menurun sebagai akibat adanya angsuran harga pokok. ${ }^{34}$

Peraturan Bank Indonesia Nomor 14/14/ PBI/2012 tentang Transparansi dan Publikasi Laporan Bank, menghendaki pelaporan kondisi keuangan bank syariah dilakukan secara transparan. Di dalam peraturan tersebut dinyatakan bahwa bank wajib menyusun dan menyajikan laporan keuangan bank. Laporan keuangan bank merupakan bentuk pertanggungjawaban manajemen terhadap pihakpihak yang kepentingan dengan kinerja bank yang dicapai selama periode tertentu. Laporan tersebut bertujuan untuk menyediakan informasi yang menyangkut posisi keuangan, kinerja bank, perubahan posisi keuangan, arus kas, serta informasi-informasi lainnya yang bermanfaat bagi pengguna laporan keuangan. ${ }^{35}$

Lebih lanjut, berdasarkan buku Pedoman Akuntansi Perbankan Indonesia, tujuan laporan keuangan bank adalah untuk memberikan informasi tentang posisi keuangan, kinerja, perubahan ekuitas, arus kas, dan informasi lainnya yang bermanfaat bagi pengguna laporan keuangan dalam rangka membuat keputusan ekonomi serta menunjukkan pertanggungjawaban manajemen atas penggunaan sumber daya yang dipercayakan kepada mereka. ${ }^{36}$ Laporan keuangan bank terdiri atas laporan tahunan, laporan keuangan publikasi triwulanan, dan laporan keuangan publikasi bulanan. Selain itu, bank juga wajib membuat laporan keuangan konsolidasi dan laporan publikasi lain. ${ }^{37}$

Publikasi laporan bank syariah dilakukan dalam bentuk laporan keuangan publikasi triwulan dalam mata uang rupiah, antara lain mencakup laporan keuangan, komitmen dan kontinjensi, transaksi spot dan transaksi derivatif. Selain itu, laporan keuangan publikasi mencakup jumlah dan kualitas aset produktif dan informasi lainnya, rasio keuangan bank, perhitungan Kewajiban Penyediaan Modal Minimum (KPMM), dan informasi mengenai komposisi pemegang saham dan susunan pengurus ${ }^{38}$ Kemudian, laporan keuangan publikasi bank syariah lainnya yang secara khusus adalah laporan sumber dan penggunaan dana zakat, infaq dan shadaqah (ZIS). Selain itu, laporan sumber dan penggunaan dana qardh, dan laporan perubahan dana investasi terikat. ${ }^{39}$

Di dalam pembiayaan murabahah, penyusunan dan penyajian laporan keuangan tersebut dapat dilakukan secara anuitas dan proporsional. Penggunaan metode anuitas dan proporsional memberikan peluang bagi bank syariah untuk membuat laporan akuntansi lebih fleksibel. Pelaksanaan penggunaan metode tersebut telah diatur melalui SEBI Nomor 15/26/DPbs/2013 tentang Pelaksanaan Pedoman Akuntansi Perbankan Syariah Indonesia (PAPSI).

\footnotetext{
Adiwarman A. Karim, 2011, Bank Islam: Analisis Fiqh dan Keuangan, Raja Grafindo Persada, Jakarta, hlm. 282.

Ketentuan Umum angka (2) Fatwa Dewan Syariah Nasional Nomor 84/DSN-MUI/XII/2012 tentang Metode Pengakuan Pendapatan Murabahah di Lembaga Keuangan Syariah (LKS).

Adiwarman, Loc.cit.

Ismail, 2011, Akuntansi Bank: Teori dan Aplikasi dalam Rupiah, Kencana, Jakarta, hlm. 14-15.

Anonimus, 2008, Pedoman Akuntansi Perbankan Indonesia (Revisi 2008), Bank Indonesia dan Ikatan Akuntansi Indonesia (IAI), Jakarta, hlm. 5 .

Pasal 2 Peraturan Bank Indonesia Nomor 14/14/PBI/2012 tentang Transparansi dan Publikasi Laporan Bank.

Pasal 7 ayat (1) Peraturan Bank Indonesia Nomor 14/14/PBI/2012 tentang Transparansi dan Publikasi Laporan Bank.

Pasal 7 ayat (2) Peraturan Bank Indonesia Nomor 14/14/PBI/2012 tentang Transparansi dan Publikasi Laporan Bank.
} 
Di dalam PAPSI dinyatakan bahwa pengakuan pendapatan murabahah secara non-tunai dapat menggunakan metode anuitas (efektif) atau metode proporsional (flat). Penggunaan metode anuitas didasarkan pada asumsi bahwa subtansi pembiayaan murabahah dikategorikan sebagai kegiatan pembiayaan (financing). Dengan demikian, pencatatan transaksi tersebut menggunakan PSAK Nomor 55 Tahun 2011 tentang Instrumen Keuangan: Pengakuan dan Pengukuran, PSAK Nomor 50 Tahun 2010 tentang Instrumen Keuangan: Penyajian, PSAK Nomor 60 tentang Instrumen Keuangan: Pengungkapan dan PSAK lain yang relevan, sepanjang tidak bertentangan dengan prinsip syariah. ${ }^{40}$

Selain itu, bank syariah juga dapat memilih metode proporsional (flat) dalam melakukan pengakuan pendapatan murabahah secara non-tunai. Penggunaan metode proporsional dikategorikan secara substansi sebagai transaksi jual beli atau bank sebagai penjual dan nasabah sebagai pembeli. Dengan demikian, pencatatan transaksi murabahah wajib menggunakan PSAK 102 tentang Akuntansi Murabahah. ${ }^{41}$

Metode anuitas dan proporsional dalam pengakuan pendapatan murabahah mempunyai beberapa perbedaan perlakuannya, antara lain adalah. ${ }^{42}$ Pada metode anuitas, pendapatan dan beban yang terkait langsung dengan pembiayaan murabahah dikapitalisasi dengan nilai pembiayaan murabahah sehingga diperoleh nilai efektif yang berbeda dengan nilai kontrak pembiayaan. Kemudian, perbedaan nilai efektif dengan nilai kontrak murabahah diamortisasi sesuai jangka waktu akad dengan menggunakan metode effective rate. Selain itu, pendapatan margin murabahah yang diakui tidak boleh melampaui margin murabahah yang telah disepakati pada akad.

Adapun penggunaan metode proporsional, pendapatan dan beban yang terkait langsung dengan pembiayaan murabahah tidak dikapitalisasi dengan nilai pembiayaan murabahah. Kemudian, pendapatan dan beban yang terkait langsung dengan pembiayaan murabahah diakui selama jangka waktu akad dengan menggunakan metode yang sama dengan pengakuan pendapatan murabahah. Selain itu, bank mengakui pendapatan margin murabahah sesuai dengan proporsi atau perbandingan antara nilai pokok murabahah dan margin murabahah pada akad murabahah.

Penggunaan metode anuitas dan proporsional bertujuan untuk menerapkan pelaporan keuangan bank syariah secara baik, akurat, terukur, dan sesuai dengan prinsip syariah melalui akuntansi syariah. Akuntansi syariah berawal dari adanya data dasar yang berupa dokumen pembukuan yang berisikan informasi transaksi yang dilakukan oleh entitas syariah. Transaksi syariah berlandaskan paradigma dasar bahwa alam semesta diciptakan oleh Tuhan sebagai amanah (kepercayaan Ilahi) dan sarana kebahagiaan hidup bagi seluruh umat manusia untuk mencapai kesejahteraan hakiki secara material dan spiritual (falah). Paradigma dasar tersebut menekankan pada setiap aktivitas umat manusia memiliki akuntabilitas dan nilai Ilahiyah yang menempatkan perangkat syariah dan akhlak sebagai parameter baik dan buruk, benar, dan salah aktivitas usaha. Paradigma tersebut akan membentuk integritas yang membantu terbentuknya karakter tata kelola yang baik (good governance) dan disiplin pasar (market discipline) yang baik. $^{43}$ Selain itu, sumber utama hukum Islam adalah Al-qur'an yang menetapkan beberapa hukum dan aturan bahwa semua orang percaya dan mengikutinya. Hampir 550 (lima ratus lima puluh) ayat di dalamnya memiliki aplikasi hukum secara langsung (ini disebut ayat-ayat hukum), dan sekitar 10 (sepuluh) menangani masalah yang berkaitan dengan keuangan dan ekonomi seperti penjualan dan larangan bunga. Selanjutnya, sumber ke dua adalah sunnah atau hadist. Sunnah terdiri dari

\footnotetext{
Lihat Bagian IV Akad Jual Beli, IV.1 Murabahah, angka 09, huruf (a) Pedoman Akuntansi Perbankan Syariah 2013.

Lihat Bagian IV Akad Jual Beli, IV.1 Murabahah, angka 09, huruf (b) Pedoman Akuntansi Perbankan Syariah 2013.

Lihat, Bagian IV Akad Jual Beli, IV.1 Murabahah, angka 10, huruf (a) dan (b) Pedoman Akuntansi Perbankan Syariah 2013.

Wiroso, 2011, Akuntansi Transaksi Syariah, Ikatan Akuntansi Indonesia, Jakarta, hlm. 27.
} 
kumpulan ajaran dan perbuatan dikaitkan dengan (atau disetujui oleh) Nabi. Sunnah menambahkan penjelasan yang terkandung di dalam Al-qur'an dan melengkapinya. ${ }^{44}$ Oleh karena itu, keuangan Islam berasal dari perintah yang ditemukan di dalam Alqur'an dan hadist Nabi Muhammad SAW. ${ }^{45}$

Penggunaan metode anuitas dan proporsional dalam pengakuan pendapatan murabahah harus dilakukan secara transparan, akuntabel, dan sesuai prinsip syariah. Adapun prinsip syariah dalam pembiayaan murabahah adalah berdasarkan Fatwa DSN Nomor 4/DSN-MUI/IX/2000 tentang Murabahah, antara lain adalah bank dan nasabah harus melakukan akad murabahah yang bebas riba, barang yang diperjualbelikan tidak diharamkan oleh syariat Islam, bank membiayai sebagian atau seluruh harga pembelian yang telah disepakati kualifikasinya. Selain itu, bank membeli barang yang diperlukan nasabah atas nama bank sendiri secara sah sah dan bebas riba, bank harus menyampaikan semua hal yang berkaitan dengan pembelian, misalnya pembelian dilakukan secara hutang, dan bank kemudian menjual barang tersebut kepada nasabah dengan harga jual senilai harga beli plus keuntungannya. Dalam kaitan ini, bank harus memberitahukan secara jujur harga pokok barang kepada nasabah berikut biaya yang diperlukan. Selanjutnya, prinsip syariah dalam murabahah adalah nasabah membayar harga barang yang telah disepakati tersebut pada jangka waktu tertentu yang telah disepakati untuk mencegah terjadi penyalahgunaan atau kerusakan akad, pihak bank dapat mengadakan perjanjian khusus dengan nasabah, dan jika bank hendak mewakilkan kepada nasabah untuk membeli barang dari pihak ketiga, akad jual beli murabahah harus dilakukan setelah barang secara prinsip menjadi milik bank. ${ }^{46}$

Lebih lanjut, metode anuitas dan proporsional juga dilakukan menurut kebiasaan yang berlaku di dalam lembaga keuangan Islam. Artinya, metode tersebut merupakan metode yang sudah biasa diterapkan di dalam lembaga keuangan Islam dan memberikan kemanfaatan (mashlahah) bagi pertumbuhan bank syariah. Selain itu, metode tersebut juga tidak memberikan kerugian (kedhaliman) bagi nasabah. Di dalam Fatwa Dewan Syariah Nasional Nomor 84/DSN-MUI/XII/2012 tentang Metode Pengakuan Pendapatan Murabahah di Lembaga Keuangan Syariah dinyatakan bahwa pengakuan keuntungan al-Tamwil bi alMurabahah dalam bisnis yang dilakukan oleh Lembaga Keuangan Syariah boleh dilakukan secara Proporsional dan secara Anuitas selama sesuai dengan 'urf (kebiasaan) yang berlaku di kalangan LKS. ${ }^{47}$

Berdasarkan ketentuan fatwa tersebut menunjukkan bahwa prinsip syariah harus memenuhi unsur-unsur materiil dan formal. Unsurunsur materiil antara lain perjanjian murabahah harus bebas riba, barang yang dijadikan objek murabahah adalah halal sesuai syariat, dan barang dan harga telah dilakukan kualifikasi sebelumnya. Di samping itu, unsur-unsur formal antara lain pembelian barang dilakukan atas nama bank syariah, transparansi dalam pembelian barang dan disampaikan kepada pembeli, bank syariah menjual kembali barang setelah mengambil keuntungan, nasabah membayar harga jual pada saat yang telah ditentukan, bank dapat membuat perjanjian khusus untuk menghindari kerusakan perjanjian, dan bank dapat mewakilkan pembelian barang murabahah kepada nasabah dan murabahah dapat dilaksanakan setelah barang menjadi kepemilikan bank syariah. Selain itu, metode anuitas dan proporsional sesuai dengan kebiasaan yang berlaku di dalam akuntansi perbankan syariah.

Kepatuhan terhadap unsur-unsur materiil dan formal tersebut, serta menjalankan akuntansi

44 Karim Djaraouane, et al., "Choice of Governing Law in Islamic Finance Agreements", International Business Law Journal, Vol. 2, No. 2, 2009, hlm. 116.

45 Vogel, et al., dalam Sherin Galal Abdullah Mouawad, “The Development of Islamic Finance: Egypt as a Case Study", Journal of Money Laundering Control, Vol. 12, No. 1, 2009, hlm. 76.

46 Fatwa DSN No. 4/DSN-MUI/IX/2000 tentang Murabahah.

47 Ketentuan Khusus, Fatwa Dewan Syariah Nasional Nomor 84/DSN-MUI/XII/2012 tentang Metode Pengakuan Pendapatan Murabahah di Lembaga Keuangan Syariah (LKS). 
berdasarkan metode anuitas dan proporsional sebagaimana telah diatur melalui SEBI Nomor 15/26/DPbs/2013 tentang Pelaksanaan Pedoman Akuntansi Perbankan Syariah Indonesia (PAPSI). Hal tersebut menunjukkan bahwa bank syariah telah melakukan transparansi dan publikasi laporan bank syariah kepada masyarakat. Masyarakat juga berhak mengetahui secara transparan keuangan karena mereka mempunyai andil dalam mendukung pengembangan perbankan syariah.

\section{Kesimpulan}

Dasar hukum metode anuitas dan proporsional dalam pengakuan keuntungan murabahah adalah Peraturan Bank Indonesia Nomor 14/14/PBI/2012 tentang Transparansi dan Publikasi Laporan Bank Syariah. Selanjutnya, Surat Edaran Bank Indonesia Nomor 15/26/DPbs/2013 tentang Pelaksanaan Pedoman Akuntansi Perbankan Syariah Indonesia. Metode anuitas dan proporsional tersebut sesuai dengan ketentuan syariah Hal ini berdasarkan Fatwa DSN Nomor 84/DSN-MUI/XI/2012 tentang Metode Pengakuan Keuntungan Pembiayaan Murabahah pada Lembaga Keuangan Syariah. Berdasarkan dasar hukum tersebut, secara prinsip diberlakukan metode anuitas dan proporsional tersebut berdasarkan pada 'uruf (kebiasaan) yang berlaku di lembaga keuangan syariah dan tidak bertentangan dengan prinsip syariah.

Metode anuitas dan proporsional sebagai bentuk komitmen lembaga keuangan syariah dalam mewujudkan transparansi dan laporan keuangan bank syariah. Metode anuitas secara substansi dikategorikan sebagai kegiatan pembiayaan sehingga mengacu pada PSAK Nomor 50 (Revisi 2010) tentang Instrumen Keuangan; Penyajian. PSAK Nomor 55 (Revisi 2011) tentang Instrumen Keuangan; Pengakuan dan Pengukuran. PSAK Nomor 60 tentang Instrumen Keuangan; Pengungkapan. Adapun metode proporsional, secara substansi dikategorikan sebagai kegiatan jual beli sehingga mengacu pada PSAK Nomor 102 tentang Murabahah. Metode ini menjembatani akuntansi perbankan syariah yang belum diatur melalui PSAK Nomor 102 tentang Murabahah.

Diperlukan penyesuaian atau revisi PSAK 102 tentang Murabahah dengan memasukkan rambu-rambu yang menggunakan metode anuitas. Penyatuan metode proporsional dan anuitas dalam satu panduan standar akuntansi murabahah dapat memudahkan bagi bank syariah untuk menyesuaikan dengan kondisi akuntansi masing-masing bank. Selain itu, bank syariah dapat bersaing dengan bank-bank lain dengan memberikan pembiayaan murabahah dengan harga yang kompetitif. Dengan demikian, pengaturan yang terkait dengan PSAK 102 tentang Murabahah perlu diatur secara lebih luas yang tidak hanya mengatur penjual dan pembeli tetapi juga mengatur pihak pembiayaan.

\section{DAFTAR PUSTAKA}

\section{A. Buku}

Anonimus, 2013, Pedoman Akuntansi Perbankan Syariah Indonesia, Bank Indonesia, Jakarta. Anonimus, 2008, Pedoman Akuntansi Perbankan Indonesia (Revisi 2008), Bank Indonesia dan Ikatan Akuntansi Indonesia (IAI), Jakarta.

Anwar, Syamsul, 2007, Studi Hukum Islam Kontemporer, RM Books, Jakarta.

Ismail, 2011, Akuntansi Bank: Teori dan Aplikasi dalam Rupiah, Kencana, Jakarta.
Istanto, F. Sugeng, 2007, Penelitian Hukum, Ganda, Yogyakarta.

Karim, Adiwarman A, 2011, Bank Islam; Analisis Fiqh dan Keuangan, Raja Grafindo Persada, Jakarta.

Soekanto, Soerjono, 2007, Pengantar Penelitian Hukum, Universitas Indonesia Press, Jakarta. Wiroso, 2011, Akuntansi Transaksi Syariah, Ikatan Akuntansi Indonesia, Jakarta. 


\section{B. Artikel Jurnal}

Ali, Ali Abdulrahim, "The Role of Islamic Jurisprudence in Finance and Development in the Muslim World", Company Lawyer, Vol. 31, No. 4, Maret 2010.

Djaraouane, Karim, et al., "Choice of Governing Law in Islamic Finance Agreements", International Business Law Journal, Vol. 2, No. 2, 2009.

Garas, Samy Nathan, et al., "Shari'a Supervision of Islamic Financial Institutions", Journal of Financial Regulation and Compliance, Vol. 9, No. 15, Januari 2008.

Hanif, Atif, "Islamic Finance: an Overview", International Energy and Taxation, Law Review, Vol. 1, No. 15, Januari 2008.

Jabbar, Siti Faridah Abdul, "Insider Dealing: Fraud in Islam?”, Journal of Financial Crime, Vol. 19, No. 2, 2012.

Kepli, Mohd Yazid Bin Zul, "Islamic Finance in Hong Kong”, Hong Kong Law Journal, Vol. 42, No. 3, 2012.

Lindsey, Tim, "Between Piety and Prudence: State Syariah and the Regulation of Islamic Banking in Indonesia”, Sydney Law Review, 34 Sydney L. Rev. 107, Maret 2012.

Maurer, Bill, "Anthropological and Accounting Knowledge in Islamic Banking and Finance: Rethinking Critical Accounts", The Journal of the Royal Anthropological Institute, Vol. 8, No. 4, Desember 2002.

Mouawad, Sherin Galal Abdullah, "The Development of Islamic Finance: Egypt as a Case Study", Journal of Money Laundering Control, Vol. 12, No. 1, 2009.

Nasution, Nur Sanita, "Pajak Berganda Menghambat Perbankan Syariah", Jurnal Ekonomi Syariah Muamalah, Vol. 6, Mei 2009.

Tabari, Nima Mersadi, "Islamic Finance and the Modern World: the Legal Principles Governing Islamic Finance in International Trade", Company Lawyer, Vol. 31, No. 8, 2010.
Taman, Salma, "The Concept of Corporate Social Responsibility in Islamic Law", Indiana International \& Comparative Law Review, 21 Ind. Int'1 \& Comp. L. Rev. 481, 2011.

Wilson, Rodney, "The Issue of Interest and the Islamic Financing Alternatives", Journal of International Banking Law, Vol. 13, No. 1, 1997.

Wisham, Ismail, et al, "Special Legal Features of the Islamic Wa'd or Pledge: Comparison with the Conventional Law on Promise Within the Sphere of Islamic Finance", International Journal of Law and Management, Vol. 53, No. 3, 2011.

\section{Makalah}

Karim, Rifaat Ahmed Abdel, "Accounting and Auditing Standards for Islamic Financial Institutions", Makalah, Proceedings of the Second Harvard University Forum on Islamic Finance: Islamic Finance into the $21^{\text {st }}$ Century Cambridge Massachusetts, Center for Middle Eastern Studies, Cambridge, 1999.

\section{Artikel Koran}

Murdiati, Ani, "Ekonomi dan Bisnis Syariah: Pembiayaan BMS Dominan Murabahah", Harian Republika, 1 April 2009.

Kushartanto, Ismi, "Ekonomi dan Bisnis: Pembiayaan UMKN BNI Syariah Capai Rp. 195 M", Harian Republika, 22 April 2009.

\section{E. Sumber Internet}

Bank Indonesia, "Statistik Perbankan Syariah (Islamic Banking Statistics) Juli 2013. http://www.bi.go.id/web/id/Statistik/ Statistik+Perbankan/Statistik+ Perbankan+Syariah/sps_0713.htm, diakses 4 Oktober 2013.

Bank Indonesia, "Arsitektur Perbankan Indonesia", http://www.bi.go.id/web/id/Perbankan/Arsi tektur+Perbankan+Indonesia/, diakses 29 September 2013. 
Bank Indonesia, "Arsitektur Perbankan Indonesia: Program Peningkatan Kualitas Pengaturan Perbankan", http://www. bi.go.id/web/id/Perbankan/Arsitektur+ Perbankan+Indonesia/Pengaturan, diakses 29 September 2013.

Bank Indonesia, "Perbankan Syariah: Sekilas Perbankan Syariah di Indonesia", http://www.bi.go.id/web/id/Perbankan/ Perbankan+Syariah/, diakses 29 September 2013.

Deloitte, "Murabahah Anuitas Perspektif Baru Lembaga Keuangan Syariah". http://www. deloitte.com/id, diakses 20 September 2013.

Feroz, Ehsan Habib, et al., "Grameen La Riba Model: A Strategy for Global Poverty Alleviation”, http://ssrn.com/abstract $=1257859$, diakses 20 September 2013.

IFSB, "Defining New Standards in Islamic Finance", http://www.ifsb.org/, diakses 20 September 2013.

Usmani, Maulana Taqi, "Murabahah", http:// www.accountancy.com.pk/docs Iislam_ murabahah. Pdf., diakses 20 September 2013.

\section{F. Peraturan Perundang-Undangan}

Undang-Undang Nomor 21 Tahun 2008 tentang Perbankan Syariah (Lembaran Negara Republik Indonesia Tahun 2008 Nomor 94 Tambahan Lembaran Negara Republik Indonesia Nomor 4867).

Peraturan Bank Indonesia Nomor 14/14/PBI/2012 tentang Transparansi dan Publikasi Laporan Bank.

Surat Edaran Bank Indonesia Nomor 15/26/ DPbs/2013 tentang Pelaksanaan Pedoman Akuntansi Perbankan Syariah Indonesia (PAPSI).

Fatwa Dewan Syariah Nasional Nomor 84/DSNMUI/XII/2012 tentang Metode Pengakuan Pendapatan Murabahah di Lembaga Keuangan Syariah (LKS).

Fatwa Dewan Syariah Nasional Nomor 4/DSNMUI/IX/2000 tentang Murabahah. 